\title{
Laboratory and field evaluation of certain wild plant extracts against Aphis fabae Scop. (Homoptera: Aphididae) and its predators
}

\author{
Ragab Shaker Abdel-Rahman ${ }^{1 *} \mathbb{D}$, Ismail Abd elkhalek Ismail', Tarik Abdelhalim Mohamed², \\ Mohamed Elamir F. Hegazy ${ }^{2,3}$ and Khaled Abdelhady Abdelshafeek ${ }^{2,4}$
}

\begin{abstract}
Background: Broad bean (Vicia faba L.) is considered one of the most essential food crops in Egypt. Aphis fabae Scop. (Homoptera: Aphididae) causes a considerable damage to bean plants as well as to other leguminous crops. The present study dealt with laboratory and field trials to evaluate the effectiveness of some plant extracts against A. fabae and two predatory species.

Results: The effectiveness of six plant extracts viz Ballota undulata (BU), Teucrium polium (TP), Phlomis aurea (PA) (Lamiaceae) - Pulicaria incisa (PI), Seriphidium herba-alba (SHA) (Asteraceae), and Euphorbia saint catherine (ESC) (Euphorbiaceae) against the bean aphid (A. fabae) and on the two predators, Chrysoperla carnea (Steph.) and Coccinella undecimpunctata L., was determined in both laboratory and field. Results showed that BU, TP, and SHA were the most toxic extracts to aphids, followed by PA and PI, while the ESC was the least toxic one. The lethal effects, expressed as percent mortalities, were 74.3, $73.2,72.7,65.9,62.5$, and $56.8 \%$, respectively. All mortality rates were significantly different than the control. Regarding the effect on the predators, insignificant differences were observed between the tested extracts and the control. In the field, the tested plant extracts were efficient for controlling the aphid without a harmful effect on the predators. The extracts had a various positive effect on crop yield; it was increased.

Conclusion: The six tested plant extracts, evaluated against A. fabae, and two predatory species showed efficiency in aphid control and safety to the predators in the field.
\end{abstract}

Keywords: Aphis fabae, Plant extracts, Efficiency, Predators, Faba bean

\section{Background}

Broad bean (Vicia faba L.) is one of the most essential food crops in Egypt. The most notorious pest attacking this field crop is the bean aphid, Aphis fabae Scop. (Homoptera: Aphididae), which causes a considerable damage to bean plants as well as to other leguminous crops. Because aphids have become resistant to most of the conventional chemical insecticides, frequent insecticide applications have become needed for its control (Zhu et al. 2016). The use of botanical extracts for the control of aphids can be a possible alternative as safe, locally available and less expensive materials for pest

\footnotetext{
* Correspondence: ragab_shaker@yahoo.com

${ }^{1}$ Agricultural and Biological Research Division, Pests and Plant Protection Department, National Research Centre, 33rd ElBohouth St. - Dokki, Giza 12622, Egypt

Full list of author information is available at the end of the article
}

control (Farag and Ismail 1999; Megersa 2016; Peris and Kiptoo 2017 and Dehariya et al. 2018).

The Sinai Peninsula is an epicenter of desert medicinal plants. The distribution and utilization of the active constituents such as aromatic substances of these plants attracted the attention of many ecologists, taxonomists, entomologists, and phytochemists (Abd El-Wahab et al. 2004 and Hikal et al. 2017). South Sinai region contains about 472 plant species, including 19 Egyptian endemic species, 115 of medicinal interest, and approximately 170 species used in folk medicine (Fayed and Shaltout 2004). The wild plant species, selected for this study, based on the unique ecosystem giving rise to great plant diversity. Isman (2006), and Singh and Singh (2016) reported that many of the plant substances such as terpenes, flavonoids, alkaloids, phenols, and other related 
compounds have been considered to be used as antifeedants, insecticides, or repellents.

The present study dealt with laboratory and field trials to evaluate the effectiveness of six plant extracts against the bean aphid, A. fabae, and its two predatory species C. carnea and C. undecimpunctata. The effects on the quantity of the crop yield were also determined.

\section{Material and methods}

Plant materials

Six plants species (Pulicaria incisa (PI), Ballota undulata (BU), Teucrium polium (TP), Euphorbia saint catherine (ESC), Seriphidium herba-alba (SHA), and Phlomis aurea (PA)) were collected from Saint Catherine (South Sinai Governorate, Egypt). Plants were identified and voucher specimens were deposited in the Herbarium of Saint Catherine Protectorate, Egypt. The collections were performed under the permission of Saint Catherine Protectorate for scientific purposes, and official permission was granted from the National Research Centre, Egypt.

\section{Rearing of aphids}

In the field at Monshaat Fadel, Al-Ayat, Giza governorate, Egypt, Aphis fabae was found during 2017. A stock culture of $A$. fabae was maintained on broad bean seedlings previously planted in pots under laboratory conditions of $25 \pm 2{ }^{\circ} \mathrm{C}$ and $65 \pm 5 \%$ R.H.

\section{Rearing of predators}

Larvae of the lacewing, Chrysoperla carnea (Steph.), and the ladybird beetle, Coccinella undecimpunctata L., were collected from the field, reared individually in glass tubes $(1 \times 5 \mathrm{~cm})$, and provided daily with a plenty of aphid's nymphs until pupation. Two generations were reared under the laboratory conditions before being used.

\section{Laboratory assessment} Preparing of plant extracts

About $100 \mathrm{~g}$ of each of the plant species tested was air-dried and then powdered and extracted with $\mathrm{MeOH}-\mathrm{H}_{2} \mathrm{O}$ (7:3). The extracts were concentrated in a vacuum, using a rotary evaporator to obtain extracts containing varying polarity compounds. Aqueous emulsions were prepared by dissolving $5 \mathrm{~g}$ of each extract in $100 \mathrm{ml}$ distilled water, using Tween-80 as the emulsifier agent. A concentration of $5 \%$ of each extract was used in all treatments.

Plant extracts at the concentration of 5\% were sprayed directly on potted seedlings carrying both aphids and second larvae of the two predators. Predators were collected from the field sample, ten aphids and three larvae of each predator/pot. Ten potted seedlings were used for each treatment, five for each predator. Equal numbers of planted pots were similarly sprayed with water, and the emulsifier served as the control. Mortality rates were calculated $48 \mathrm{~h}$ after spraying and were corrected according to Abbott's formula (Abbott 1925).

\section{Field assessment}

To evaluate the effectiveness of the botanical extracts on the rates of aphid's population, experiments were carried out in a broad bean field at Monshaat Fadel, Al-Ayat, Giza Governorate, Egypt, 2017. Broad bean variety (Giza 40) was sown. Agronomic activities were practiced in all experiment plots.

The experiments included six treatments (plant extracts) plus untreated control, arranged as a complete randomized block design with five replicates each (6-m wide $\times 7$-m long $=42 \mathrm{~m}^{2}$ ). Broad bean in full coverage was secured by the use of a knapsack sprayer fitted with one nozzle by different extracts. Spray program was initiated 30 days after planting in the field. When broad bean cultivation was found to be infested naturally with aphids, samples of ten plants were collected at random from each plot early in the morning, before treatment,

Table 1 Toxicity of six tested plant extracts against $A$. fabae and its predators under laboratory conditions

\begin{tabular}{lllll}
\hline Treatment & $\%$ & \multicolumn{2}{l}{ Corrected percent mortality 48 h after spraying* } \\
\cline { 3 - 5 } & C. fabae & C. carnea & C. undecimpunctata \\
\hline BU & 5.0 & 74.3 & 10.8 & 9.9 \\
TP & 5.0 & 73.2 & 10.3 & 9.4 \\
SHA & 5.0 & 72.7 & 11.1 & 10.9 \\
PA & 5.0 & 65.9 & 9.6 & 11.9 \\
PI & 5.0 & 62.5 & 8.3 & 11.2 \\
ESC & 5.0 & 56.8 & 9.5 & 9.7 \\
Control & 0.0 & 13.0 & 9.0 & 8.0 \\
LSD & - & 2.1 & 3.2 & 3.4 \\
\hline
\end{tabular}

${ }^{*} N=10$ 
Table 2 The effect of six plant extracts on Aphis fabae infesting broad bean and mean numbers and percent reduction in population at Monshaat Fadel, Al-Ayat, Giza governorate, Egypt, 2017

\begin{tabular}{|c|c|c|c|c|c|c|c|c|c|c|}
\hline \multirow[t]{3}{*}{ Treatment } & \multirow{3}{*}{$\begin{array}{l}\% \\
\text { Concentration }\end{array}$} & \multirow{3}{*}{$\begin{array}{l}\text { Before } \\
\text { Spraying } \\
\text { (MN) }\end{array}$} & \multicolumn{8}{|c|}{ After indicated period } \\
\hline & & & \multicolumn{2}{|c|}{1 week } & \multicolumn{2}{|c|}{2 weeks } & \multicolumn{2}{|c|}{3 weeks } & \multicolumn{2}{|c|}{ Average } \\
\hline & & & $\mathrm{MN}$ & $\% R$ & $\mathrm{MN}$ & $\% R$ & $\mathrm{MN}$ & $\% R$ & $\mathrm{MN}$ & $\% R$ \\
\hline BU & 5.0 & 9.4 & 5.3 & 83.2 & 6.3 & 87.8 & 10.7 & 84.0 & 7.4 & 85.2 \\
\hline TP & 5.0 & 8.3 & 4.9 & 82.3 & 12.4 & 72.9 & 18.6 & 68.5 & 11.9 & 73.1 \\
\hline SHA & 5.0 & 8.1 & 4.8 & 82.0 & 12.7 & 71.5 & 15.6 & 72.9 & 11.0 & 74.5 \\
\hline PA & 5.0 & 7.8 & 5.7 & 78.2 & 14.2 & 67.0 & 16.4 & 70.5 & 12.1 & 73.9 \\
\hline PI & 5.0 & 8.8 & 6.1 & 79.3 & 15.5 & 68.0 & 17.5 & 72.1 & 13.0 & 72.3 \\
\hline ESC & 5.0 & 8.1 & 6.7 & 75.3 & 17.3 & 61.2 & 20.3 & 64.8 & 14.8 & 65.7 \\
\hline Control & 0.0 & 8.8 & 29.5 & - & 48.5 & - & 62.7 & - & 46.9 & - \\
\hline LSD & & 0.8 & 1.5 & - & 3.4 & - & 3.8 & - & 4.9 & - \\
\hline
\end{tabular}

and after intervals of 1,2 , and 3 weeks post applications. The collected samples were kept in muslin bags until they were thoroughly examined in the laboratory. Counts of aphids were made and percentages of reduction in pest population were calculated according to the equation of Henderson and Tilton 1955 as follows:

$$
\text { \%Reduction }=\left(1-\frac{T_{\mathrm{a}} \times C_{\mathrm{b}}}{T_{\mathrm{b}} \times C_{\mathrm{a}}}\right) \times 100,
$$

where:

$T_{\mathrm{a}}=$ no. of individuals in treated plots after treatment

$T_{\mathrm{b}}=$ no. of individuals in treated plots before treatment

$C_{\mathrm{a}}=$ no. of individuals in control plots after treatment

$C_{\mathrm{b}}=$ no. of individuals in control plots before treatment

In the second series of experiments, the effectiveness of the botanical extracts and the numbers of the two predators were determined by counting their individuals weekly after spraying. Data were obtained from ten plants/plot/treatment/weekly. The control samples were sprayed with water and used for comparison.

Table 3 Mean numbers of C. carnea on broad bean plants after spraying with plant extracts, 2017

\begin{tabular}{lllll}
\hline Treatment & Before treatment & First week & Second week & Third week \\
\hline BU & 17.0 & 20.2 & 21.0 & 20.3 \\
TP & 19.5 & 17.0 & 18.0 & 16.0 \\
SHA & 17.5 & 19.0 & 19.4 & 20.1 \\
PA & 19.0 & 18.0 & 17.5 & 17.0 \\
PI & 19.5 & 19.2 & 20.0 & 19.3 \\
ESC & 19.5 & 22.5 & 21.5 & 20.5 \\
Control & 17.5 & 27.0 & 25.0 & 26.0 \\
LSD & 8.01 & 11.2 & 9.4 & 10.9 \\
\hline
\end{tabular}

$N=10$
Assessments were also extended to determine the effect of different applications on the crop yield. After harvest, the seeds were separated from the plants, collected, and dried, and the average weight per plot (42 $\mathrm{m}^{2}$ ) was recorded. Five averages were taken for each treatment as well as the untreated control.

Data were statistically analyzed by ANOVA, using the Instat V2.03 computer program test, and mean values were separated by the least significant difference (LSD) procedure (Snedecor and Cochran 1980) at a probability of $5 \%$.

\section{Results}

Laboratory assessment of plant extracts

Results obtained in Table 1 show that the $\mathrm{MeOH}-\mathrm{H}_{2} \mathrm{O}$ extracts of $\mathrm{BU}, \mathrm{TP}$, and SHA were the most toxic to aphids, followed by PA and PI, while the ESC was the least one. With respect to the value of percent mortalities, they attained $74.3,73.2,72.7,65.9,62.5$, and $56.8 \%$, respectively, compared to $13.0 \%$ in the control. The effect of the extracts on the mortality of $C$ carnea and $C$. undecimpunctata is represented in Table 1. Their mortality rates were largely similar and did not differ

Table 4 Mean numbers of $C$. undecimpunctata on broad bean plants after spraying with plant extracts, 2017

\begin{tabular}{lllll}
\hline Treatment & Before treatment & First week & Second week & Third week \\
\hline BU & 21 & 28.2 & 26.3 & 29.5 \\
TP & 25 & 22.0 & 23.0 & 21.0 \\
SHA & 25 & 22.2 & 24.5 & 22.3 \\
PA & 21 & 19.2 & 21.3 & 18.0 \\
PI & 23 & 26.3 & 23.5 & 25.2 \\
ESC & 21 & 22.4 & 23.1 & 25.0 \\
Control & 25 & 34.2 & 30.9 & 35.4 \\
LSD & 8.2 & 18.2 & 14.3 & 19.5 \\
\hline
\end{tabular}


Table 5 Yield assessment of broad bean seeds out of different plant extracts treatments, 2017

\begin{tabular}{llll}
\hline Treatments & Mean yield $\left(\mathrm{kg} / 42 \mathrm{~m}^{2}\right)^{\mathrm{a}}$ & Calculated yield $\left(\mathrm{kg} / \mathrm{fed}^{-1}\right)$ & Increase in yield \\
\hline BU & 8.2 & 820 & 1.3 \\
TP & 9.5 & 950 & 1.5 \\
SHA & 8.2 & 820 & 1.3 \\
PA & 8.6 & 860 & 1.3 \\
PI & 9.5 & 950 & 1.5 \\
ESC & 7.7 & 770 & 1.2 \\
Control & 6.4 & 640 & 1.0 \\
LSD & 3.1 & 110.2 & -
\end{tabular}

${ }^{\mathrm{a}}$ Data obtained from five replicates $/ 42 \mathrm{~m}^{2} /$ treatment

significantly than the control. These percentages ranged between 9 and $11 \%$ in all treatments, and it proved to be safe.

\section{Field assessment}

Results summarized in Table 2 show that the mean numbers of bean aphid before treatments ranged $7.8-$ 9.4 aphids/treatment. The mean numbers of all treatments after applications increased with the increase of the period. In the different periods, the mean numbers ranged from 4.8 to $6.7,6.3$ to 17.3 , and 10.7 to 20.3 aphids in 1,2 , and 3 weeks, respectively. The highly significant effect was found among the three periods and their controls. Mean numbers in controls were $29.5,48.5$, and 62.7 aphids, respectively.

Concerning the reduction of infestation, $B U$ was the most effective one than the other tested plant extracts; it achieved 87.8 and $84.0 \%$ reduction in population after 2 and 3 weeks of treatment, respectively, while ESC gave only 61.2 and $64.8 \%$ in the same period (Table 2). This effectiveness of $B U$, TP, and $S H A$ extracts may be due to the existence of diterpenes and flavonoids in high concentrations. On the other hand, there was an insignificant difference between PI and ESC. They showed less residual activities against aphids giving averages of reductions 72.3 and $65.7 \%$, respectively (Table 2).

It could be concluded that the tested plant extracts were efficient for aphid control without being harmful to the predators in the field (Table 3 and 4).

\section{Effect of different treatments on bean yield}

Results in Table 5 indicate that the different treatments had various positive effects on bean yield. A slight increase occurred but did not differ significantly than the control. The increase over the control ranged from 1.2 to 1.5 . The average calculated yield in the control was $640 \mathrm{~kg} \mathrm{fed}^{-1}$, compared to $950 \mathrm{~kg} \mathrm{fed}^{-1}$, after using TP and PI extracts (Table 5).

\section{Discussion}

Laboratory results are in agreement with those obtained by Farag and Ismail (1999) who found that the BU, TP, and PA already showed a strong insecticidal and antifeedant activity against some insects. Many chemical constituents were isolated from these plants viz diterpenoids, sesquiterpenes, iridoids, flavonoids aglycones, and glycosides (Cespedes et al. 2015; Singh and Singh 2016). The chemical constitutes of Euphorbia species exhibited many activities as antibacterial, anti-inflammation, and antioxidant (Reda et al. 2017). Peris and Kiptoo (2017) and Alghamdi (2018) stated that the botanical pesticides can be used in control of aphids, as they are environmentally safe, having low toxicity to mammals, fish, and pollinators.

Field results agree with the observation of Boutkhil et al. 2011 who found that the essential oil of Seriphidium herba-alba (previously named Artemisia herbaalba) caused $85.41,90.44$, and $87.45 \%$ reduction in the population of B. tabaci, A. gossypii, and T. tabaci, respectively. Also, Mvumi and Maunga (2018) stated that Lantana treatments showed a significant mortality effect on aphids at all times.

Data in Table 3 showed that there is no effect of different treatments on the population of the two tested predators, C. carnea and C. undecimpunctata, in the field.

The present finding confirms the data obtained by Farag and Ismail (1999) who reported that the plant extracts of the Compositae-tested plants were nontoxic to $C$. carnea and C. undecimpunctata, when they are used for controlling aphids and whitefly. Ali et al. (2015) revealed that the combined use of $M$. olerifera, A. indica, and E. globules leaf extracts was very effective against Diuraphis noxia and is used as an alternative instead of synthetic chemicals.

Regarding the effect of different treatments on bean yield, similar findings were reported and it was investigated that the application of neem oil $1 \%$ registered the cost-benefit ratio of $1: 1.79$ and was found the most economical. 


\section{Conclusions}

In conclusion, this study indicates that among the six extracts, the extracts of $\mathrm{BU}, \mathrm{TP}$, and SHA were the most toxic to aphids, and their effectiveness may be due to the existence of diterpenes and phenolics in high concentrations. The tested plant extracts were efficient for aphid control without being harmful to the predators in the field. The different treatments achieved a slight increase in the bean yield. Finally, using the plant extracts (botanical insecticides) in aphid control program can be recommended.

\section{Abbreviations \\ BU: Ballota undulata; ESC: Euphorbia saint catherine; PA: Phlomis aurea; PI: Pulicaria incisa; SHA: Seriphidium herba-alba; TP: Teucrium polium}

\section{Funding}

No fund founded

\section{Availability of data and materials}

All data generated or analyzed during this study are included in this article.

\section{Authors' contributions}

RSA, IAI, M-EH, and KAA designed experiments. TAM, M-EH, and KAA collected the plants and conducted the phytochemistry. IAI and RSA set up and conducted the biological and field experiments, and after that, they analyzed the data and wrote the article. All authors revised the article and read and approved the final manuscript.

\section{Ethics approval and consent to participate}

Not applicable (this study does not involve human participants, human data, or human tissue).

\section{Consent for publication}

Not applicable

\section{Competing interests}

The authors declare that they have no competing interests.

\section{Publisher's Note}

Springer Nature remains neutral with regard to jurisdictional claims in published maps and institutional affiliations.

\section{Author details}

${ }^{1}$ Agricultural and Biological Research Division, Pests and Plant Protection Department, National Research Centre, 33rd ElBohouth St. - Dokki, Giza 12622, Egypt. ${ }^{2}$ Phytochemistry Department, National Research Centre, 33 El-Bohouth St., Dokki, Giza 12622, Egypt. ${ }^{3}$ Department of Pharmaceutical Biology, Institute of Pharmacy and Biochemistry, University of Mainz, Staudinger Weg 5, 55128 Mainz, Germany. ${ }^{4}$ Chemistry Department, Faculty of Science, Albaha University, Albaha, Kingdom of Saudi Arabia.

Received: 16 January 2019 Accepted: 8 March 2019

Published online: 21 March 2019

\section{References}

Abbott WS (1925) A method computing the effectiveness of an insecticides. J Econ Ent 18:265-267

Abd El-Wahab RH, Zaghloul MS, Moustafa AA (2004) Conservation of medicinal plants in St. Catherine Protectorate, South Sinai. I. Evaluation of ecological status and human impact. In: Proceedings of first international conference on strategy of Egyptian herbaria, Giza, Egypt, pp 231-251

Alghamdi AS (2018) Insecticidal effect of four plant essential oils against two aphid species under laboratory conditions. J Appl Biol Biotechnol 6(2):27-3028
Ali H, Qasim M, Saqib HSA, Arif M, Islam S (2015) Synergetic effects of various plant extracts as bio-pesticide against wheat aphid (Diuraphis noxia L.) (Hemiptera: Aphididae). Afr J Agric Sci Technol 3(7):310-315

Boutkhil S, El Idrissi M, Chakir S, Derraz M, Amechrouq A, Chbicheb A, El Badaoui K (2011) Antibacterial and antifungal activity of extracts and essential oils of Seriphidium herba-alba (Asso) Soják and their combination effects with the essential oils of Dysphania ambrosioides (L) Mosyakin \& Clemants. Acta Bot Gallica 158(3):425-433

Cespedes CL, Aqueveque PM, Avila JG, Alarcon J, Kubo I (2015) New advances in chemical defenses of plants: researches in calceolariaceae. Phytochem Rev 14:367-380

Dehariya SK, Shukla A, Barde SK, Ahirwar K (2018) Efficacy of botanical pesticides against sucking insects pests in Brinjal. Int J Curr Microbiol App Sci 7(01): 1930-1935. https://doi.org/10.20546/ijcmas.2018.701.232

Farag NA, Ismail IA (1999) The comparative effect of certain insecticides and plant extracts on cabbage aphid, Brevicoryne brassicae L. and its natural enemies. J Egypt Ger Soc Zool 30(E):281-289

Fayed A, Shaltout K (2004) Conservation and sustainable use of medicinal plants in arid and semi-arid eco-systems project. In: Flora of Saint Catherine Protectorate, and Floristic Survey of the Mountainous Southern Sinai: Saint Catherine Protectorate, final report. GEF, UNDP) (project no: 12347/12348), Egypt

Henderson CF, Tilton EW (1955) Test with acaricides against the brown wheat mites. J Econ Entomol 48:157-161

Hikal WM, Baeshen RS, Said-Al Ahl HAH (2017) Botanical insecticide as simple extractives for pest control. Cogent Biology 3(1):1-16. https://doi.org/10. 1080/23312025.2017.1404274

Isman MB (2006) Botanical insecticides, deterrents, and repellents in modern agriculture and an increasingly regulated world. Annu Rev Entomol 51:45-66

Megersa A (2016) Botanicals extracts for control of pea aphid (Acyrthosiphon pisum; Harris). J Entomol Zool Stud 4(1):623-627

Mvumi C, Maunga PR (2018) Efficacy of lantana (Lantana camara) extract application against aphids (Brevicoryne brassicae) in rape (Brassica napus) over varied periods of time. Afr J Biotechnol 17(8):249-254

Peris NW, Kiptoo JJ (2017) Potential of botanical extracts in the control of kale aphids (Brevicoryne brassicaea) and their effect on the parasitic wasp (Aphidius ervi). Asian Res J Agric 4(3):1-6

Reda EH, Saleh IA, El Gendy AG, Talaat ZA, Hegazy M-EF, Hagga EG (2017) Chemical constituents of Euphorbia sanctae-catharinae Fayed essential oil: a comparative study of hydro-distillation and microwave-assisted extraction. Adv Pharm Res 1(3):155-159

Singh R, Singh M (2016) Botanicals: The green pesticides. In: Sayyed RZ, Reddy MS, Al-Turki Al (eds) Recent Trends in PGPR Research for Sustainable Crop Productivity, First edn. Scientific Publishers, INDIA, pp 137-147. https://doi. org/10.13140/RG.2.1.2863.7047

Snedecor GW, Cochran WG (1980) Statistical method, 7th edn. lowa state University Press, Ames (IA), p 507

Zhu F, Lavine L, O'Neal S, Lavine M, Foss C, Walsh D (2016) Insecticide resistance and management strategies in urban ecosystems. Insects 7(1):2. https://doi. org/10.3390/insects7010002

\section{Submit your manuscript to a SpringerOpen ${ }^{\circ}$ journal and benefit from:}

- Convenient online submission

- Rigorous peer review

- Open access: articles freely available online

High visibility within the field

Retaining the copyright to your article

Submit your next manuscript at $>$ springeropen.com 